\title{
The activity of Rhaphidophora pinnta Lf. Schott leaf on MCF-7 cell line
}

\author{
Masfria $^{1}$, Urip Harahap ${ }^{1}$, Maratua Pandapotan Nasution ${ }^{1}$, Syafruddin Ilyas ${ }^{2}$ \\ ${ }^{1}$ Faculty of Pharmacy, University of Sumatera Utara, Medan, Indonesia \\ ${ }^{2}$ Faculty of Mathematics and Natural Sciences, University of Sumatera Utara, Medan, Indonesia \\ Email: fia.mustafa@yahoo.com
}

Received 31 May 2013; revised 29 June 2013; accepted 13 July 2013

Copyright (C) 2013 Masfria et al. This is an open access article distributed under the Creative Commons Attribution License, which permits unrestricted use, distribution, and reproduction in any medium, provided the original work is properly cited.

\begin{abstract}
Ekor naga's leaf (Rhaphidophora pinnata (Lf) Schott) is a type of vines and climbing plant. The leaves are elongated round and hollowed inside. This plant had been using for the treatment of breast cancer. Extraction with percolation method has been done in ekor naga's leaves with ethanol, and fractionated by nhexane, chloroform and ethyl acetate using liquidliquid extraction (LLE). Cytotoxicity assay of ethanol extract, n-hexane fraction, chloroform fraction, ethyl acetate fraction and water fraction against MCF-7 cells were done using MTT method (3-(4,5-dimetiltiazol-2-il)-2,5-diphenyl tetrazolium bromide). Phytochemical screening results showed the presence of the compounds such as triterpenoida/steroid, alkaloid, flavonoid, tannin, and saponin. n-hexane fraction was positive for the presence of triterpenoida/steroid, chloroform fraction containing alkaloids, saponin and triterpenoid; ethyl acetate fraction contained, flavonoid, tannin, and the fraction of water indicated the presence of tannin and saponin. Secondary metabolite compounds in ethanol extract, chloroform fraction and ethyl acetate fraction gave positive results against MCF-7 cells. Cytotoxicity assay of MCF-7 cell line showed that crude ethanol extracts had 112.240 $\mathrm{mcg} / \mathrm{ml} \mathrm{IC} \mathrm{I}_{50}$ chloroform fraction $\mathrm{IC}_{\mathbf{5 0}}$ was $\mathbf{5 9 . 0 8 2}$ $\mathrm{mcg} / \mathrm{ml}$, and ethyl acetate fraction $\mathrm{IC}_{50}$ was 812.663 $\mathbf{m c g} / \mathbf{m l}$.
\end{abstract}

Keywords: Ekor Naga's Leaf; Haphidophora Pinnata; MCF-7 Cells; MTT Method; Cytotoxic Assay

\section{INTRODUCTION}

Breast cancer is one of the worldwide deathly cancer type after lung, liver and colon cancer. It is the main enemy of women and currently in the first rank of danger. Identification of breast cancer cases worldwide has in- creased from about 640.000 in 1980 to 1.6 million by 2010 in developing country [1]. Patients with breast cancer are mainly caused by the diet, such as the selection of foods and drinks contain preservatives, coloring agents and beverages that contain alcohols [2].

Cause of cancer usually cannot be known with certainty because it is a combination of a set of factors including genetics, environment, foods containing chemicals, viruses, for example Papilloma Virus, which caused genital warts/genital, cytomegalo virus that caused Kaposi sarcoma/cancer of vascular system marked by blood red skin lesions, Hepatitis B virus, hormonal imbalance, free radicals, psychological and emotional factors [3].

The efforts for developing anticancer drugs had been continued intensively, both derived from chemicals and natural sources. Some research showed that many of the plants contain a variety of chemical compounds as potential anticancer. One of those things that has became scientists' observation is traditional medicine. This research is done because the potential of traditional medicine has long been believed by the people to cure the disease [4].

One of the plants that can be used for the cancer treatment is ekor naga's leaves (Rhaphidophora pinnata (Lf) Schott), from Araceae family. Some people have used the boiling water for the treatment of cancer. Polyphenolic compounds (flavonoids, tannins and saponins) are generally effective as antioxidant and could kill the growth of abnormal cells (tissue) and uncontrolled cell, which is one of the causes of cancer [5].

Pre-eliminary screening test for active compounds contained in the extract was the toxicity test on the shrimp larvae Artemia salina L. using the brine shrimp test method with $\mathrm{LC}_{50}$ values of crude ethanol extract 19.686 $\mathrm{mcg} / \mathrm{ml}$, n-hexane fraction $505.82 \mathrm{mcg} / \mathrm{ml}$, ethyl acetate fraction $28.84 \mathrm{mcg} / \mathrm{ml}$ and ethanol fraction $128.82 \mathrm{mcg} / \mathrm{ml}$ [6-9]. Acute toxicity test with oral administration in female mice up to doses of $5000 \mathrm{mg} / \mathrm{kg}$ BW did not reveal 
any mortality up to 7 days and no physiological changes in the body of mice. Therefore, the $\mathrm{LD}_{50}$ value of the ethanol extract of ekor naga's leaves cannot be calculated and it was declared the value $\mathrm{LD}_{50}$ was greater than 5000 $\mathrm{mg} / \mathrm{kg} / \mathrm{BW}$ in female mice.

One model of breast cancer cells used MCF-7 cells that had been patented by the institute of Michigan Cancer Foundation-7 (MCF-7). MCF-7 cells are cell type isolated in 1970 from a woman's breast tissue of Caucasian race. MCF-7 cells have been used for a variety of in vitro research on breast cancer because they have some of the same characteristics associated with breast epithetlial estrogen in the form of the ability to process estradiol via estrogen receptors in the cytoplasm. It makes the MCF-7 cells give positive result to estrogen (ER) recipeent in the control cells [10].

In order to find new drugs for the treatment of breast cancer, the in vitro cytotoxicity test of the ethanol extract (crude) and fractions (n-hexane, chloroform, ethyl acetate and water) of ekor naga leaves against MCF-7 cells had been done.

\section{MATERIALS AND METHODS}

\subsection{Materials and Reagents}

The material used in this study was ekor naga's leaves. The chemicals used were, n-hexane (Merck), 96\% ethanol (Merck), chloroform (Merck), ethyl acetate (Merck), a solution of dimethylsulfoxide (DMSO) pro 99.5\% GC (Sigma), Roswell Park Memorial Institute Medium (RPMI 1640), hepes (Sigma), 3-(4,5-dimetiltiazol-2-il)-2, 5-diphenyl tetrazolium bromide (MTT), Fetal Bovine Serume (FBS), Penicillin-Streptomycin, silica gel $\mathrm{GF}_{254}, \mathrm{H}_{2} \mathrm{SO}_{4} \mathrm{P}$ (Merck), methanol (Merck), acetone (Merck), Amphoterisin B, Sodium dodecyl sulphate in $0.01 \mathrm{~N} \mathrm{HCl}$, Doxorubicin, MCF-7 cell line.

\subsection{Phytochemical Screening}

Phytochemical screening of ekor naga leaves powder, ethanol extract and fractions of class compounds included examining alkaloids, glycosides, anthraquinone glycosides, saponins, flavonoids, tannins, and triterpenoida/steroid.

\subsubsection{Examination of Alkaloids}

Crude leaves powder weighed $0.5 \mathrm{~g}$ and then diluted with $2 \mathrm{~N}$ hydrochloric acid and distilled water, heated over a water bath for 2 minutes, cooled and filtered. Filtrate was tested with the addition of reagent of alkaloid such as Mayer, Bauchardat, and Dragendorff.

\subsubsection{Examination of Glycosides}

Crude leaves powder was refluxed for 2 hours with a mixture of ethanol-water (7:3) and $2 \mathrm{~N}$ hydrochloric acid, then filtered. Filrate was added with a solution of lead (II) acetate $0.4 \mathrm{M}$, then shaken, and filtered. Filtrate was extracted with isopropanol-chloroform mixture (2:3). Water extract was collected and evaporated at a temperature of not more than $50^{\circ} \mathrm{C}$. The remaining part was dissolved in methanol and added with $2 \mathrm{ml}$ of water and reagent Molish. Then slowly $2 \mathrm{ml}$ of concentrated sulfuric acid was added through the tube wall. The formation of a purple ring was formed.

Examination of anthraquinone glycosides Crude leaves powder was heated with $5 \mathrm{ml}$ of $2 \mathrm{~N}$ sulfuric acid, then cooled it room temperature, the mixture then was added with $10 \mathrm{ml}$ of benzene, shaken and allowed to stand. Benzene layer was separated and shaken with $2 \mathrm{ml}$ of $2 \mathrm{~N}$ $\mathrm{NaOH}$, allowed stand. Water layer is red and colorless benzene layer showed the presence of anthraquinone.

\subsubsection{Examination of Saponin}

Crude leaves powder was inserted into a test tube, then hot water was added. The mixture was cooled then shaken vigorously for 10 seconds. If the $1-10 \mathrm{~cm}$ tall foam was formed and stable for not less than 10 minutes and did not disappear with the addition of 1 drop of $2 \mathrm{~N}$ hydrochloric acid, then it was positive for saponin.

\subsubsection{Examination of Flavonoide}

Crude leaves powder was shaken with hot water for $5 \mathrm{~min}$ and filtered under hot conditions, the filtrate was added magnesium powder, and concentrated with hydrochloric acid and amyl alcohol, then shaken. It showed flavonoid with positive if a red or yellow or orange colour in the lining of amyl alcohol was formed [11].

\subsubsection{Examination of Tannin}

Crude leaves powder was boiled in water for 3 minutes, cooled and filtered. The filtrate was added with 1 - 2 drops of $1 \%$ iron (III) chloride. If there is blue-black or blackish green indicates the presence of tannins [11].

\subsubsection{Examination of Steroid/Triterpenoida}

Crude leaves powder was macerated with $20 \mathrm{ml} \mathrm{n}$-hexane for 2 hours, then filtered. Filtrate should was evaporated in the evaporating dish, then added with a few drops of Liebermann-Burchard reagent. Onset of blue or blue-green color showed the presence of steroid, while the color is red, pink or purple that indicated triterpenoid [12].

\section{PLANT MATERIAL AND EXTRACTION OF EKOR NAGA'S LEAVES}

Extracts were performed using 96\% ethanol by percolation method [13].

Dried ekor naga's leaves were weighed approxinately 
$900 \mathrm{~g}$ and soaked with n-hexane for 24 hours to eliminate the fat content. The residue was filtered and aerated until the n-hexane solvent evaporated, then soaked in ethanol for 3 hours for percolation the mass was moved into the percolator while carefully pressed and slowly poured the solvent until the liquid began to drip and the sample was still embed in the solvent. After that the percolator was closed and left for 24 hours. Then the tap was opened and the liquid was allowed to drip at rate of $1 \mathrm{ml}$ per minute. Solvent was added continuously until there was a layer of liquid on top of sample. Percolation was continued until the last out of liquid evaporated leaving no residue. Resulted liquid was evaporated using rotary evaporator with temperature $\pm 40^{\circ} \mathrm{C}$, and then freeze dried until highly viscous extract was obtained as much as $138 \mathrm{~g}$. Proceed the fractionation by liquid-liquid extraction.

\subsection{Liquid-Liquid Extraction of Ethanol Extract}

Fractionation was performed using solvents with different polarity from non-polar to polar such as: n-hexane, chloroform, ethyl acetate, and water.

A total of $100 \mathrm{~g}$ of ethanol extract was dissolved in ethanol and then added with distilled water, the mixture was put in a separating funnel and added with $200 \mathrm{ml}$ of n-hexane, shaken, allowed to stand until there were 2 separated layers. n-hexane layer (upper layer) was taken with decantation methode. Fractionation was done if the n-hexane layer was colorless (clear) and did not give color with Liebermann-Burchard reagent. The fractionation was continued with addition of $200 \mathrm{ml}$ of chloroform in the shaker (separating funnel). The sample was shaker and then allowed to stand until there were 2 separated layers. The chloroform layer was taken (bottom layer). Fractionation was done until the chloroform was layer colorless gave negative result with Dragendorff reagent, then add $200 \mathrm{ml}$ of ethyl acetate in water layer, shaken, and then allowed to stand until there are 2 separate layers. Fractionation is done until the color of the layer and the ethyl acetate is clear then fraction of water is taken, all the fractions obtained were evaporated by vacuum rotary evaporator. Each of the obtained fractions was assay for cytotoxic activity.

\subsection{In Vitro Assay for Cytotoxic Activity}

Five milligrams of ethanol extract and the fractions (nhexane, chloroform, ethyl acetate and water) were dissolved with the aid of $100 \mu \mathrm{L}$ of DMSO, then diluted with cultur media in order to get a series of concentration (500, 250, 125, 62.50, $31.25 \mathrm{mcg} / \mathrm{ml})$. The culture media was used as negative control and doxorubicin was used as positive control with series concentration of $(200,100,50$, $25 \mathrm{mcg} / \mathrm{ml}$ ). Each concentration was made replication for 3 times.

\subsection{Cytotoxic Assay with MTT Method}

MCF-7 cells were growth in 96 wells microplate in order to obtain the density of $1 \times 10^{4}$ cells/wells and incubated for 24 hours to get good growth. After the medium was replaced with a new one it was added with $100 \mu \mathrm{L}$ of test solution in a variety of concentrations and incubated again for 24 hours. At the end of incubation, the media was be removed and washed with PBS solution, and then each of the wells was added with $10 \mu \mathrm{L}$ MTT (3-(4.5-dimetiltiazol-2-il)-2.5-diphenyl tetrazolium bromide) $0.5 \%$ in PBS. Incubation was continued for 4 hours at $37^{\circ} \mathrm{C}$ until formazan was formed. The living cells were converted MTT into dark-blue formazan. MTT reaction was stopped by the stopper reagent (100 $\mu \mathrm{L}$ of Sodium dodecyl sulfate), and then incubated overnight at room temperature. The absorbance was read by ELISA reader at a wavelength of $595 \mathrm{~nm}$. The absorbance results were converted into percentage of life reads. MTT method was performed according by Mossman [14] with modification of stopper reagent.

\subsection{Data Analysis}

Data obtained in the form of absorbance values of each which converted into percentage of living cell and calculated with the following formula:

$$
\% \text { Living Cells }=\frac{\text { Absorbance Cell With Treatmen }- \text { Absorbance Control Media }}{\text { Absorbance of control cell }- \text { Absorbance Contro Media }} \times 100 \%
$$

Then IC $_{50}$ concentrations calculated were by probit analysis using SPSS 17, in order to obtain linearity between log concentration and percentage of live cells. $\mathrm{IC}_{50}$ is the concentration that causes cell death for $50 \%$ of the population.

\section{RESULTS AND DISCUSSION}

Extraction of plant material was done to get secondary metabolites from plant material which is used as medicine. Percolation extraction had been done by ethanol with obtained $117.4 \mathrm{~g}$ from $900 \mathrm{~g}$ of dried "ekor naga" leaves.

\subsection{Phytochemical Screening}

The identification of leaves powder and ethanol extract of ekor naga's leaves chemical compounds were done 
with some color reagents to obtain the class of secondary metabolites information. The results could be seen in Table 1.

Flavonoids as antioxidants can prevent and cope with of cancer. Mechanism of action: flavonoids in cancer treatment can inhibit the cancer cells growth through the inhibition of cell cycle mechanism, induce apoptosis, inhibition of angiogenesis, antiproliferative or a combination of these mechanisms [15].

\subsection{Liquid-Liquid Extraction}

Solvent extraction with n-hexane, chloroform and ethyl acetate obtained $3.681 \mathrm{~g}$ of n-hexane fraction, $1.680 \mathrm{~g}$ of chloroform fraction, $0.572 \mathrm{~g}$ of ethyl acetate fraction, and $24.809 \mathrm{~g}$ of water fraction. The screening results of n-hexane fraction with Lieberman-Burchard (LB) reagent gave a blue purple color, which was likely to contain triterpenoid/steroid compound. The chloroform fraction gave pink color wich may contained triterpenoid. Triterpenoid is an antioxidant as a catcher of free radicals that can kill brain cells and also could revitalize blood vessels

Ethyl acetate fraction with $\mathrm{FeCl}_{3}$ reagent gave a positive result, which was likely to contain polyphenolic compounds that can inhibit the growth of cancer cells through the inhibition of cancer cell growth, induce apoptosis, inhibition of angiogenesis, antiproliferative or a combination of these mechanisms [15].

\subsection{Assay Anticancer}

The results of the extract and some fractions treatment on MCF-7 cells can be seen in Figure 1. The morphology of MCF-7 cell due to the treatment of n-hexane and water fractions did not provide significant changes to the untreated cells (control cells). While the ethanol extract (crude), chloroform and ethyl acetate fractions with high concentration, i.e. $500 \mathrm{mcg} / \mathrm{ml}$ could be seen dead cells which was round (Figure 1).

Cytotoxicity assay were performed to confirm the cy-

Table 1. Phytochemical screening simplex and ethanol extract.

\begin{tabular}{cccc}
\hline No & $\begin{array}{c}\text { Secondary } \\
\text { metabolites }\end{array}$ & $\begin{array}{c}\text { Leaves } \\
\text { powder }\end{array}$ & Ethanol extract \\
\hline 1 & Tannin & + & + \\
2 & Alkaloids & + & + \\
3 & Flavonoid & + & + \\
4 & Saponin & + & + \\
5 & Glycosides & + & - \\
6 & $\begin{array}{c}\text { Anthraquinone } \\
\text { glycosides }\end{array}$ & $\begin{array}{c}\text { Yellowish- } \\
\text { brown }\end{array}$ & + \\
7 & Steroid/Triterpenoid & + & + \\
\hline
\end{tabular}

totoxic ability of the sample solution against MCF-7 cells with a quantitative colorimetric method based on the measurement of the color intensity that occurred as a result of metabolism of a substrate by living cells into colored product. This study used yellow MTT \{(3-(4,5-dimetaltiazol2-il)-2,5-diphenyl tetrazolium bromide\} to form a dark blue formazan which insoluble in water and attached to the cells. The ability of the succinate dehydrogenase enzyme to reductase tetrazolium system were included in the mitochondria of living cells $[14,16]$. The method was fast, sensitive, accurate and could be used to test large samples which automatically using a spectrophotometer [16], that also proved more reliable than cell counting using a hemocytometer [17].

The results of t-test analysis of the sample treatment with several concentrations, positive control, control cells, and media control can be seen in Figure 2.

From Figure 2, it was known that the ethanol extract (concentration of $31.25-250 \mathrm{mcg} / \mathrm{ml}$ ). The chloroform fraction (concentration of 31.25 - $500 \mathrm{mcg} / \mathrm{ml}$ ), ethyl acetate fraction (concentration of 31.25 - $500 \mathrm{mcg} / \mathrm{ml}$ ), n-hexane fraction (concentration of $500 \mathrm{mcg} / \mathrm{ml}$ ) and water fraction (concentration of $62.5-500 \mathrm{mcg} / \mathrm{ml}$ ), showed a significant difference $(\mathrm{p}<0.05)$ to the positive control, media control and control cells.

Cytotoxic test gives an overview of the potential test-

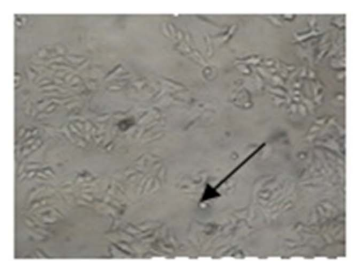

CONTROL

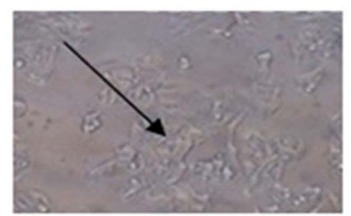

(B)

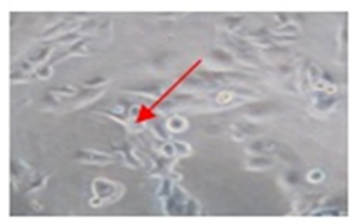

(D)

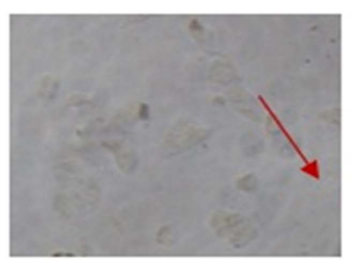

(A)

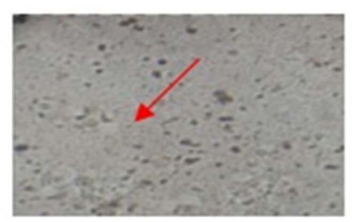

(C)

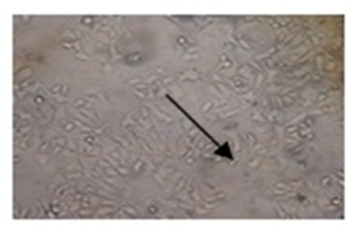

(E)
Figure 1. The effect of ethanol extract (A), hexane fraction (B), chloroform fraction (C), ethyl acetate fraction (D), and water fraction (E) of ekor naga's leaves on MCF-7 cells after incubation for 24 hours. The observation of cell morphology at 24 hours was performed using an inverted microscope with $400 \times$ magnification. Living cells were indicated by black arrows, whereas dead cells were indicated by red arrows. 
ing material in inhibiting cell growth. The parameters used are the $50 \%$ of inhibition concentration $\left(\mathrm{IC}_{50}\right)$. The smaller value of IC $_{50}$ the more potential in inhibiting cell growth, as Figure 3 shows chloroform fraction $\mathrm{IC}_{50}$ was smaller than ethanol extract and ethyl acetate fraction.

Doxorubicin (Adriamycin) is used as a positive comparator and a chemotherapeutic agent against MCF-7 cells because it is currently one of anti-tumor chemotherapy drug that had been using successfully and extensively, although the side effects will increase with the increase the dose. Based on the results of the research, it was known that it has cardiotoxic effects associated with cumulative dose $[18,19]$. In addition beside it is toxic against normal tissues, it was also known as the cause of tumor cell that resistance to drugs, such as resistance of MCF-7 cells [20].

$\mathrm{IC}_{50}$ analysis results indicate that a parameter for cytotoxic potential of a test substance using probit analysis SPSS 17, was calculated from the relation between different concentrate with the percentage of live cells resulted ethanol extract $\mathrm{IC}_{50} 112.240 \mathrm{mcg} / \mathrm{ml}$, chloroform fraction $\mathrm{IC}_{50} 59.082 \mathrm{mcg} / \mathrm{ml}$, ethyl acetate fraction $\mathrm{IC}_{50}$ 812. $663 \mathrm{mcg} / \mathrm{ml}$, while the fraction of $\mathrm{n}$-hexane and

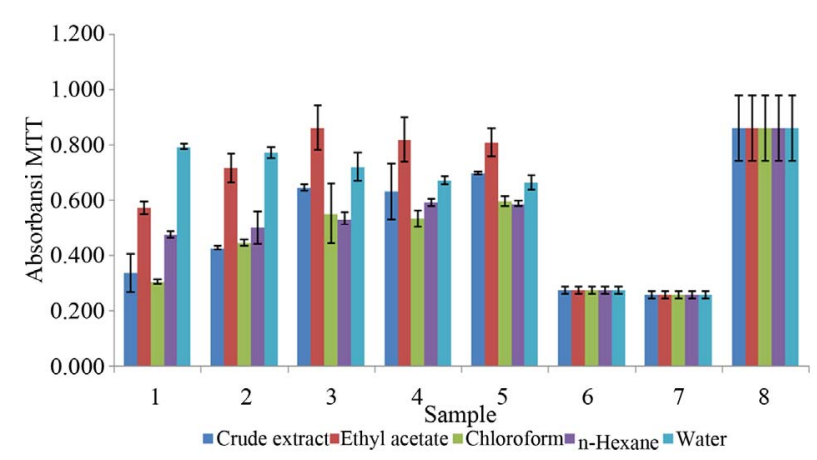

Figure 2. Effects of samples treatment to of the MTT absorbance with different concentrations. Description: 1. Extract concentration $500 \mathrm{mcg} / \mathrm{ml}$; 2. $250 \mathrm{mcg} / \mathrm{ml}$; $3.125 \mathrm{mcg} / \mathrm{ml} ; 4.62 .5$ $\mathrm{mcg} / \mathrm{ml} ; 5.31 .25 \mathrm{mcg} / \mathrm{ml}$; 6. positit control; 7. media controls; 8. control cells.

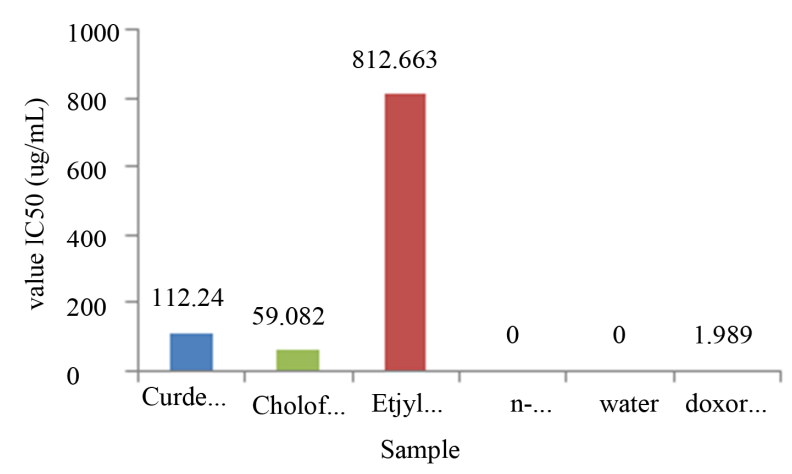

Figure 3. $\mathrm{IC}_{50}$ results with some samples Description: $\mathrm{IC}_{50}$ of n-hexane and water fractions is not detected. water didn't inhibit the growth of MCF-7 cells. Doxorubicin has $\mathrm{IC}_{50}$ of $1.989 \mathrm{mcg} / \mathrm{ml}$, when compared with doxorubicin, the samples still had lower $\mathrm{IC}_{50}$ concentration sample, which can be used to combine the sample fraction that had smaller $\mathrm{IC}_{50}$ with doxorubicin which can reduce the effect of cardiotoxic and resistancy of MCF-7 cells.

\section{CONCLUSION}

The $\mathrm{IC}_{50}$ values of ethanol extract obtained by cytotoxic assay results was $112.240 \mathrm{mcg} / \mathrm{ml}$, chloroform fraction was $59.082 \mathrm{mcg} / \mathrm{ml}$, and ethyl acetate fraction was 812.663 $\mathrm{mcg} / \mathrm{ml}$, while the fraction of n-hexane and water did not inhibit the growth of MCF-7 cells.

\section{REFERENCES}

[1] Jaknews, C. (2011) Breast cancer: Detected cases of "silent killer” increased, by the Institute for Health Metrics and Evaluation at the University of Washington in Seattle www.cancerhelps.com. Causes of Cancer (Cancer).

[2] Irmaya, H. (2011) Factors triggering the vulnerability of young women to be breast cancer, campaign, breast cancer month. Petra Christian University, Petra.

[3] Anonim. www.cancerhelps.com

[4] Wiwik, S.R., Suirta, I.W. and Sabikin, A. (2008) Isolation and Identification of potential as an antitumor compounds in bitter melon fruit flesh (Momordica charantia L.). Journal of Chemistry, 2, 1.

[5] Silalahi, J. (2006) Functional food. Publisher Canisius, Jakarta, 63-70.

[6] Masfria, Harahap, U., Nasution, M.P. and Ilyas, S. (2011) Cytotoxicity test of n-hexane extract, Ethyl Acetate and Ethanol ekor naga leaf (Rhaphidophora pinnata (Lf) Schott) by Brine Shrimp Lethality Test method (BSLT), Medan.

[7] Awik, P.D.N. (2006) Toxicity test extracts to artemia salina eucheuma alvarezii as potential anticancer preliminary study. Deed Kimindo, 2, 41-46.

[8] Meyer, B.N. (1987) Brine shrimp: A convenient general bioassay for active plant Constituents. Planta Medica, 45 31-34. doi:10.1055/s-2007-971236

[9] Aini, M.N. (2006) Anticancer activity test praskrining extract $\mathrm{n}$ hexane, dichloromethane and methanol leaf Rhaphidophora pinnata (Lf) with brine shrimp lethality test methods.

[10] Crawford, K.W. and Bowen, W.D. (2002) Sigma-2 receptor agonists activate a novel apoptotic pathway and potentiate antineoplastic drugs in breast tumor cell lines. Cancer Research, 62, 313-322.

[11] Farnsworth, N.R. (1966) Biological and phytochemical screening of plants. Journal of Pharmaceutical Sciences, 55, 259-260. doi:10.1002/jps.2600550302

[12] Harbone, J.B. (1987) Phytochemical methods. 2nd Edition, Padmawinata, Bandung. 
[13] Dep Kes, P.O.M. (1979) Indonesian pharmacopoeia. 3rd Edition, Ministry of Health, Jakarta.

[14] Mosmann, T. (1983) Rapid colorimetric assay for cellular growth and survival: Application to proliferation and cytotoxicity assays. Journal of immunological Methods, 65, 65-59. doi:10.1016/0022-1759(83)90303-4

[15] Ren, W., Qiao, Z., Wang, H., Zhu, L. and Zhang, L. (2003) Flavonoids: Promising anticancer agents. Medicinal Research Reviews, 23, 519-534. doi:10.1002/med.10033

[16] Doyle, A. and Griffiths, J.B. (2000) Cell and tissue culture for medical research. John Wiley and Sons Ltd., New York.

[17] Freimoser, F.M., Jakob, C.A., Aebi, M. and Tuor, U. (1999) The \{ MTT 3-(4,5-Dimethylthiazol-2-il)-2,5-diphenyltetrazolium $\}$ bromide assay is a fast and reliable method for colorimetric determination of fungal cell den- sities. Applied and Environmental Microbiology, 65, 3727-3729.

[18] Wattanapitayakul, S.K., Chularojmontri, L., Herunsalee, A., haruchongkolwongse, S., Niumsaku, S. and Bauer, J.A. (2005) Antioxidantsfrom screening of medicinal plants for cardioprotective effect against doxorubicin toxicity. Basic \& Clinical Pharmacology \& Toxicology, 96, 80. doi:10.1111/j.1742-7843.2005.pto960112.x

[19] National Cardiovascular Center Harapan Kita (2011) Animal studies try. GSPE (grape seed proanthocyanidin extract) effect cardiotoxic prevent doxorubicin, contributed by administrator.

[20] Conze, D., Weiss, L., Regen, P.S., Bhushan, A., Weaver, D., Johnson, P. and Rincon, M. (2001) Autocrine production of interleukin 6 causes multi drug resistance in breast cancer cells. Cancer Research, 61, 8851-8858. 